\title{
Simulation of Combustion in a Spark Ignition Engine Using Hybrid Fractal Flame Model
}
学 ○中山 孝之 (立命館大院)
正西脇 一宇 (立命館大)
Takayuki NAKAYAMA, Graduate School of Ritsumeikan University, Nojihigashi 1-1-1, Kusatsu, Shiga Kazuie NISHIWAKI, Ritsumeikan University

\section{1 緒 言}

火花点火エンジンの燃焼シミュレーションにおいて乱流予混 合伝ぱ火炎について様々なタイプの然焼モデルが提案されてい るが未だ不十分な点が多い. 本研究では, Hybrid Fractal Flame Model $^{1)}$ (以下 HFFM) を用い計算を行い, 実験結果と比較した.

\section{2 燃燒モデル}

HFFMは，層流火炎素片モデルと乱流散逸燃焼モデルを合成 したモデルで, 燃焼率 $\omega$ は乱流の燃焼率 $\omega_{T}$ と層流の燃焼率 $\omega_{L}$ から求め, 次式で示される.

$$
\begin{aligned}
& \omega=C_{R}\left\{\omega_{T} \gamma_{K}+\omega_{L}\left(1-\gamma_{K}\right)\right\} \\
& \omega_{T}=\rho_{u} c(1-c) / \tau_{K} \\
& \text { (2), } \\
& \omega_{L}=\rho_{u} S_{T}|\nabla c| \\
& \gamma_{T}=\left(l_{K} / l\right)^{3-D_{T}}
\end{aligned}
$$

ここで, $C_{R}$ はモデル定数, $\gamma_{K}$ は Kolmogorov 渦の体積割合, $\tau_{K}$ は Kolmogorov 渦の時定数, $\rho_{u}$ は末燃ガス密度, $c$ は反応進行 度， $S_{T}$ は乱流燃焼速度， $D_{T}$ はフラクタル次元である. $S_{T}$ に は, 鈴木ら ${ }^{2)}$ 開発した Fractal Dimension Growth Model（以下 FDGM）を適用した.

\section{3 計算対鮽エンジンおよび解法}

計算対象エンジンは, クボタガスエンジンEA-11-NB をベース に燃焼室の形状をディスク型に改修し，中心点火に改造した単 気筒火花点火エンジンである. 圧縮比 7.9, 燃料にはレギュラー ガソリンを用いた。

計算は軸対称円筒座標系で，質量，運動量，乱れエネルギと その散逸率，格子平均エンタルピ，末然エンタルピおよび反応 進行度の保存式を解いた。回転速度は $1000 \mathrm{rpm}, 1500 \mathrm{rpm}$, $1800 \mathrm{rpm}$ で, それぞれ当量比 $0.985,1.040,1.046$, 点火時期 $13^{\circ}$ BTDC, $14^{\circ}$ BTDC, $20^{\circ}$ BTDC である.

\section{4 計算結果および考察}

HFFM およびFDGM，Weller のモデルによるシリンダ内圧力 およひ熱発生率を実跧結果とともに図 1(a)から(c)に示す。いず れのモデルについても，1000 rpm において実験結果に合うよう にモデル定数 $C_{R}$ を調節した. HFFM は $1500 \mathrm{rpm}, 1800 \mathrm{rpm}$ にお いても実験結果とよく一致しているが，他のモデルで汕回転速 度が大きくなるほど然焼が遅れており，実測圧力との差が大き くなることがわかる. HFFM の特徴は, 乱流散逸然焼が加わっ ていることで, 式(5)で示寸乱流散冕然焼の全熱発生率に対する 割合 $R_{\omega T}$ および $\gamma_{K}$ の各回転速度における時間変化を図 2 に示 す. 図 2 より， $R_{\omega T}$ が回転速度の増加とともに大きくなること がわかる.これにより，HFFM は回転速度の変化に対しても実 測値に近い結果を得ることができると考えられる.

$$
R_{\omega T}=\omega_{T} \gamma_{K} /\left\{\omega_{T} \gamma_{K}+\omega_{L}\left(1-\gamma_{K}\right)\right\}
$$

$$
5 \text { まとめ }
$$

火花点火エンジンの燃焼過程を，HFFM を用いてシミュレー
トし, 実験結果と比較検討した. 回転速度変化の条件に対して, 燃焼過程を表現できることがわかった。

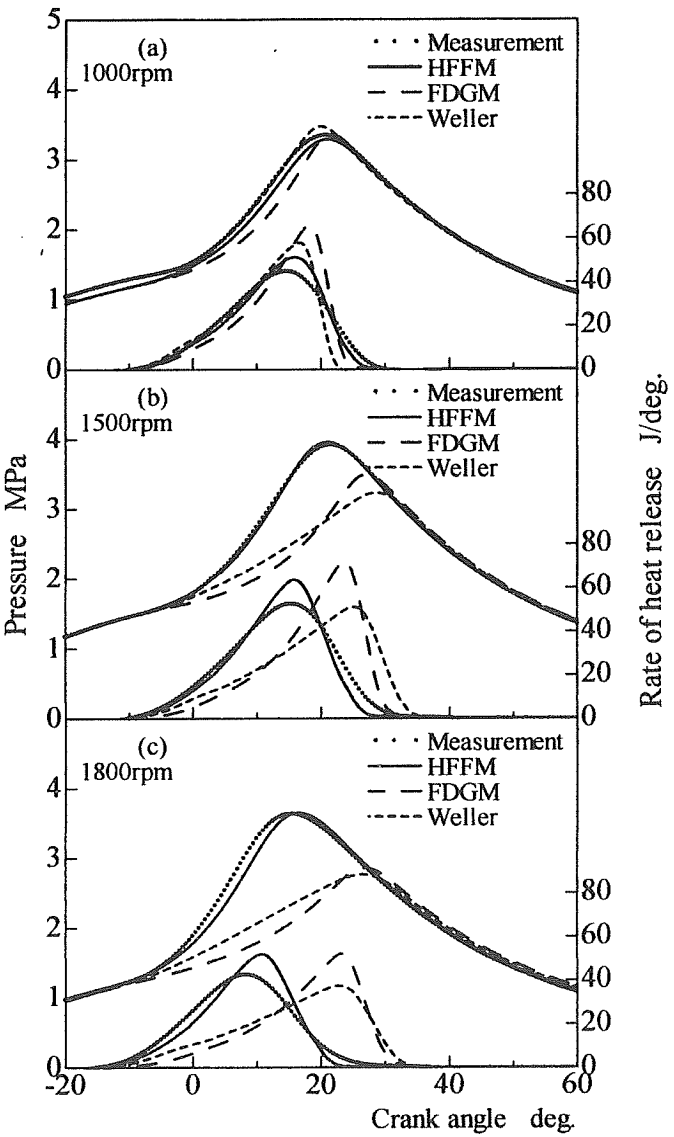

Fig. 1 Comparison of computed pressure and rate of heat release with measured ones for (a) 1000 rpm, (b) 1500 rpm and (c) 1900rpm

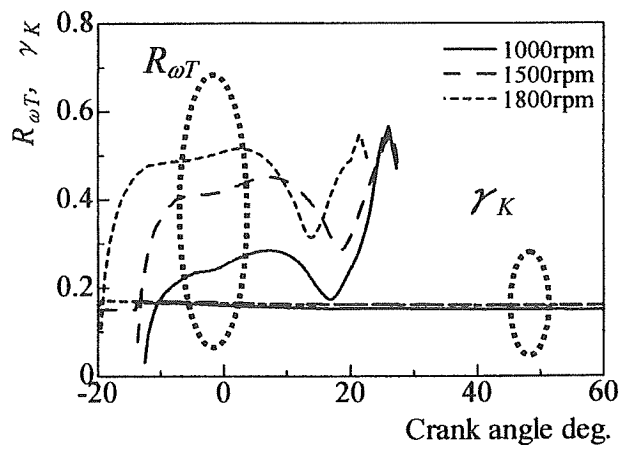

Fig. 2 Contribution of turbulent dissipation flamelet

\section{参考文献}

(1) Nishiwaki, K., Proc. COMODLA 98, pp. 35-44, 1998.

(2) Suzuki, K., SAE Paper 2004-01-1993, 2004. 